\title{
Visitor Books and Memory - Evaluating the Bautzner Straße Dresden Memorial Site's Significance for Former Stasi Prisoners' Individual Memories
}

\author{
Saskia Weise-Pötschke \\ Independent Researcher
}

\begin{abstract}
Memorial sites document aspects of history. Thus, they represent a historical past deemed relevant by the initiators in the public sphere. The former Stasi detention center and district administration in Dresden Bautzner Straße is a memorial site that is dedicated to a critical representation of the communist dictatorship in East Germany. This does, however, not tell much about the historical site's meaning to the visitors. In order to get an impression of the visitors' spontaneous reactions and thoughts, I systematically examine and categorize the memorial site's visitor books. Through these books, memorial sites offer visitors the opportunity to write down their thoughts thereby enabling an open channel of communication. My focus is on entries by persons who explicitly identify as former inmates of the very detention center they visited. They make up roughly 10 percent of all entries. I examine which thoughts former Stasi prisoners wrote down having visited their place of ordeal. What feelings and thoughts emerge after the visit? My aim is to shed light on the memorial site's significance and importance for the prisoner's individual memory by analyzing the entries' type and content. The visitor books offer an authentic and intriguing access to former political prisoners' mental world and their individual memory. This contribution connects the media representation of the communist dictatorship and its meaning for the former prisoners' individual memory.
\end{abstract}

\section{Keywords}

memorial site; Visitor Books; Visitor Studies; Ministry for State Security; GDR

\section{Introduction}

Memorial sites illustrate and interpret aspects of history that institutions, nations, or society find worthy to remember (Assmann 2007, p. 177). This is especially true of memorial sites that deal with the so-called Aufarbeitung (to reconcile oneself with the past and to identify responsibilities) of the former Ministry for State Security's (MfS) history document, a characteristic part of the German Democratic Republic (GDR), of which a lot of people suffered.

\footnotetext{
* Saskia Weise-Pötschke; saskiaweise@gmx.de
} 
Today, as public memorial sites, it is mostly former Stasi prisons that reveal the activities and crimes of the past days. This is also the case in the Bautzner Straße in Dresden, the capital of the Federal State of Saxony in East Germany. Until the political upheavals of 1989, the building hosted both the district administration and a remand center. Following the occupation by civil rights activists on December 5, 1989, the building saw its first public tour in a reunited Germany in 1994.

Since then, thousands of people from all over Germany and all over the world have visited the Stasi's former building complex for political prisoners, Bautzner Straße Dresden. It has become a memorial site that is dedicated to a critical representation of the communist dictatorship in East Germany. This, however, does not tell much about the historical site's meaning to the visitors. To gain an impression of the visitors' spontaneous reactions and thoughts, I systematically examine and categorize the memorial site's visitor books. This is a fairly new approach to the study of memorial sites, which previous visitor research works rarely considered.

Through these books, memorial sites offer visitors the opportunity to write down their thoughts, thereby enabling an open channel of communication. These comments are a spontaneous reaction to the visit and, in contrast to surveys, there is no influence by a researcher and his/her research interest. Not every visitor takes the time to write something in a visitor book. But the visitors who do put the effort into writing something down communicate something important to them. That is why analyzing these comments promises to be remarkably interesting.

After a short outline of the history and funding body of the Stasi memorial site, I want to discuss visitor books' characteristics as a source of data for empirical studies. I will provide a methodological insight into the visitor book entries' systematic analysis. My focus is on entries by persons who explicitly identify as former inmates of the very remand center that they have come to visit as free persons. I examine the thoughts that former Stasi prisoners wrote down on visiting their place of ordeal. What feelings and thoughts emerge after the visit? I aim to shed light on the memorial site's significance and importance for a prisoner's individual memory by analyzing the entries' type and content. The visitor books offer an authentic and intriguing access to former political prisoners' mental world and their individual memories. This contribution connects the media representation of the communist dictatorship to its meaning for the former prisoners and their memories. 


\section{Transforming the Stasi Facilities into a Memorial Site}

In the GDR, public memory was limited to communist victims of the national socialist dictatorship. After the reunification of Germany, the memory culture in Germany and Saxony changed. Since the early 1990s, memorial sites dealing with the communist past have been established all over East Germany. While the early communist past's memory culture focused on the dichotomy of perpetrator and victim, historians have meanwhile postulated a more extensive memory that allows ambiguities and contrariness (Gallinat and Kittel 2009, p. 312).

Today, around 100 memorial stones and monuments (Kaminsky 2016) and important memorial sites, such as Bautzen, "Runde Ecke" Leipzig, the Documentation and Information Centre Torgau, and Bautzner Straße Dresden, remind visitors of the communist past in Saxony. The memorial sites' landscape is still developing; two new memorial sites in Hoheneck and Leipzig, focusing on the communist dictatorship in the GDR, are in progress. Saxony's memorial culture has become more complex and approachable over the past years.

The former district administration center on Bautzner Straße Dresden encompassed a remand center. On October 5, 1953, the Soviet secret service handed the building complex over to the district's Stasi officials (Sieber and Thiel 2017, p. 25). In the 3 years before that, the Soviets had used these buildings as a central prison complex, where they interrogated and convicted mostly people who had perpetrated acts of resistance against the occupation power or/and the Socialist Unity Party's (Sozialistische Einheitspartei Deutschlands - SED) totalitarian rule. The 30 prison cells, $12 \mathrm{~m}^{2}$ in size, often housed more than four inmates.

Following the handover, the Stasi undertook wide-ranging reconstruction efforts, such as the U-shaped extension that blocked the view from the street. During its existence, the district administration center developed into a huge complex hosting almost all of the district's departments, including a remand center (Sieber and Thiel 2017, p. 26). This encompassed 31 departments and 16 local offices, adding up to 3,591 official employees in 1989 in the district of Dresden (Boeger and Catrain 2017, p. 40). This modern prison complex enabled confinement modeled after the Stasi's vision. The 44 cells (so-called Verwahrräume) were able to house 88 inmates at the same time. The major part of the investigation proceedings was connected to attempts to flee and repeated application for emigration (Ausreiseantrag). Bautzner Straße served as a stopover for inmates, who were later sent to their home districts. The $1980 \mathrm{~s}$ saw about 300 investigation proceedings per year. 
In the course of the demonstrations in the fall of 1989, about 5,000 protesters occupied the complex on December 5 (Kaminsky 2016, p. 400; Sieber and Thiel 2017, p. 54). The inmates were freed, and their former cells served as a secure storage room for the Stasi records that the protesters found in the complex. Following the Stasi's dissolution in January 1990 and the German reunification of October 1990, responsibility for the records was transferred to the Stasi Records Agency (Bundesbeauftragte für die Unterlagen des Staatssicherheitsdienstes der ehemaligen Deutschen Demokratischen Republik - BStU). In 1993, the BStU's Dresden field office moved from the Bautzner Straße complex to Riesaer Straße. The empty remand center opened for visitors the same year.

The association "Erkenntnis durch Erinnerung e.V." (Awareness through Memory), constituted in 1997, engaged in memorial work at the historic site. Even today, it is responsible for the memorial site. In May 2014, the enlarged memorial site, encompassing the Soviet remand cellar, as well as the administrative part including the ballroom and the district head's offices, opened. As Sieber and Thiel (2017) note, the Stasi memorial site testifies strikingly of the practice of repression and persecution in the Soviet occupation zone (Sowjetische Besatzungszone - SBZ) and the GDR. This is done through the intensity of the authentic surroundings. The nongovernmental association organizes the memorial site's guided tours, projects, and memory work. It is also a place of face-to-face encounters with former inmates and a memory place.

\section{Visitor Books' Characteristics as a Data Source}

Like in many other memorial sites, there is also a visitor book displayed at Bautzner Straße. It is located in the entry hall of the exhibition, and visitors definitely pass by it while leaving the institution. In 2008, the first visitor book provided an opportunity for comments during the institution's open house. Since 2010, it is a regular feature. Through this opportunity, memorial sites offer a channel of communication for visitors to leave their thoughts and comments as a direct reaction after the visit. For the comments' authors, the written statement is a voluntary and complementary action to their visit (Thurmair 2009, p. 37). Not every visitor is motivated to write a comment, as it is estimated that roughly $5-10 \%{ }^{1}$ of all visitors utilize this opportunity (Christmeier 2009, p. 331; Müller 2003, p. 39). By dividing the number of entries by the number of visitors per year, I was able to calculate the entry

1 Ulrich Müller identified an entry quote of $2.4 \%$ at the memorial site Düsseldorf in 2001; see Müller (2003, p. 33). 
rates (Figure 1). I identified yearly entry rates ranging from $1.0 \%$ to $2.7 \%$ (2010-2020), which is clearly lower than the estimated 5\%.

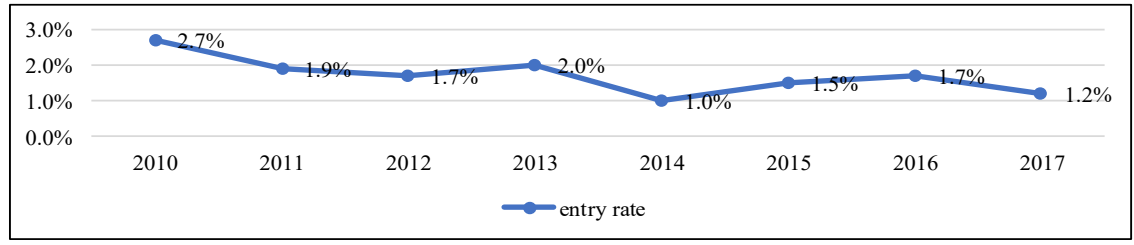

Figure 1: The visitor books' entry rates of the memorial site Bautzner Straße.

Despite this relatively low number, it is fair to say that those who leave a statement feel the urge to do so strongly, while their true motivations remain uncertain. By leaving a comment, visitors can identify themselves deliberatively (through revealing their social background) or unknowingly (through their handwriting or the entry's design) (Thurmair 2009, p. 40).

In general, visitor books contain a huge number of comments, which vary in their lengths. The order is mostly chronological. Sometimes, entries reference earlier entries. The visitor book's placement defines the entries' thematic orientation: according to the memorial site's intention, the entries should allude directly to the visit or the exhibition's content. But contrary to interviews and surveys, the comments are not influenced by a research interest or the relation between interviewer and interviewee (Macdonald 2005, p. 122).

The opportunity to leave a comment offers four options of action. First, most visitors opt for no entry. Second, by signing their entry, visitors can identify themselves. Third, the entry can be addressed to a specific addressee, and fourth, visitors can allude to certain aspects or artifacts of the exhibition (Thurmair 2009, p. 42). Numerous entries are not specifically addressed but rather generally addressed to the curators, readers of the book, or authors of other entries. The comments are the authors' written products and reflect the authors' minds only partially (Glogner-Pilz 2019, p. 32). It lies in the visitor's discretion what information and reaction are to be shared. This is also influenced by the individual's ability to express.

One challenging aspect of visitor book analysis is the fact that sociodemographic data of the comments' authors are rarely available, which renders correlation tests impossible (Macdonald 2005, p. 123). Likewise, visitors' attitudes can be hard to ascertain. However, since there is no influence of the researcher on the visitors and entries are formulated spontaneously, visitor books 
constitute a fascinating resource for research on memorial sites' effects on visitors. The visitor books' representativeness is limited by low entry rates and missing sociodemographic information. But the huge number of entries over many years offers a wide range of opinions that vindicate a systematical analysis. The social psychologist Ulrich Müller supports the idea of analyzing museums' and memorial sites' visitor books and explains that considering social science aspects, visitor books provide an empirical material, whose limited representativeness is outweighed by a high concentration and intensity of reactions and emotions (Müller 2003, p. 39).

Despite being a special kind of text, analysis of visitor books does not differ fundamentally from that of other qualitative sources (Macdonald 2005, p. 123). When evaluating the former Dresden remand center's visitor books, I followed the approach taken by previous analyses of visitor books. Entries in German and English representing the majority of comments were taken into account. Comments such as "I-was-here" and visitor signatures were excluded. I digitalized all of the entries chronologically and categorized them according to their thematic focus. Entries were assigned to up to two thematic categories. In order to reflect the variety of entries, I adjusted the categories throughout the process of digitalizing. Due to the brevity of the entries (most entries are no longer than two to three lines), detailed coding of the entries was not necessary.

\section{Visitor Books' Entries by Former Stasi Prisoners}

I analyzed five visitor books of the memorial site spanning the time period from December 2008 to January 2020. About 10\% of the entries from the first visitor book (from December 2008 to August 2012) were written by people who identified themselves as former prisoners or their relatives. Later visitor books contain fewer such entries. A reason could be that people who already visited the memorial site probably will not visit again or, if so, they probably do not leave a second comment in the visitor book.

Overall, I found 91 entries by former Stasi prisoners, including 12 comments by their relatives since the memorial site opened. The entries' lengths varied, but most authors wrote more than a short line with legible handwriting: It seems like they made an extra effort so that their message and thoughts are readable by others.

One comment was related to the time when the complex was in the hands of the Soviet occupation force. I tried to translate some of the visitor books' comments so that one can get a better impression of how they appear. I am aware that translating these entries cannot transmit all of the original 
characteristics; therefore, you find the German comment in the footnotes for those of you who can understand it and can get an impression of the language used.

In these comments, I identified more sociodemographic information than in other comments: $72.5 \%$ of the statements indicated the authors' gender. Among those who wrote a comment in these visitor books were 15 women, 40 men, and 11 couples or families. In addition, two thirds of the comments contain information about the time and/or period of arrest. This seems to be a piece of especially important information for the comments' authors to let potential readers know their time of suffering in that remand center. Information about the authors' age is scarce.

Before being used by the Stasi, the building complex was used by the Soviet occupation force as a prison center. Of the 10,000 people convicted by a Soviet court-martial in Saxony, many were sent to a labor camp in Workuta, Siberia, where they worked in the coal mines (Sieber and Thiel 2017, p. 20). One entry by a then 80 -year-old former inmate bears witness to this ordeal in a brief summary.

Preserve this memorial site as a reminder to those who were spared from political detainment. Learn from the experience. Driven roughly 5,000 kilometers to Workuta. Minus $50^{\circ}$ Celsius. Neither enough food nor clothing. About $70 \%$ of all inmates "kicked the bucket" in 40 coal mines in 12-hour shifts. Thank you to former federal chancellor Dr. Konrad Adenauer who secured the return of roughly 1,000 former prisoners of war and other detainees in 1955/56. J.S. D-55120 Mainz (June 2010) $)^{2}$

The other entries refer to political imprisonment during the Stasi era. In 14 entries, the authors provide information about their cells interior or indicated that they had found "their" former cell inside the remand center. It appears that in addition to the period of detainment, cell numbers were engraved in the former detainees' memories. This is a significant characteristic of the entries.

To paraphrase their time in prison, the comments' authors used various descriptions, as you can see in the following entries. A short addition: "Foxhole" was the Stasi's nickname for the demand center.

2 Original: "Erhaltet diese Gedenkstätte zur Mahnung an die, die von politischer Haft verschont blieben. Lernet aus der Er-fahr-ung. Ca. 5000km nach Workuta gefahren. Minus $50{ }^{\circ} \mathrm{C}$. Mangelnde Ernährung und Bekleidung. Ca. $70 \%$ aller Häftlinge "verreckten" in 40 Steinkohlenschächten bei bis zu 12 Stunden Tagesarbeit. Danke ehemalige Bundeskanzler Dr. Konrad Adenauer für die Rückführung von rd. 1000 ehemaligen Kriegsgefangenen und Zivil-Internierten im Jahre 1955/56 J.S. D-55120 Mainz" (Juni 2010). 
Today, after 56 years, we met again in the so-called "foxhole", where we had been "as a guest". We were able to identify our cells after a while. All in all people should pay more attention to the foxhole as it belongs to one of the most important places of memory to remember a state of which some say that it is no illegitimate state [Unrechtsstaat]. D. + W.N. (April 2010) ${ }^{3}$

Great opportunity to get a feeling for this time and for everyone who "lived" here, it will bring back old memories. I wish all the best for the effort of preserving everything. A former inmate, sept./oct. 1988 (Summer 2010) ${ }^{4}$

The past caught up with me. My "stay" in cell 7 from April to July 75 as a then 16-years-old boy was terrible. One year of life was wasted then, reason $\$ 213$, escaping. G.H.W. Sonnenallee (December 2011) ${ }^{5}$

51 years ago[,] I was "accommodated" in cell 25 for 80 days. It used to be a 3-man-cell with a continuous plank bed so high that it was nearly impossible to sit. Lying down was forbidden. Only thing left was to sit on the toilet by turns. There you were pushed up because they flushed the toilet from outside the cell. K.K. (September 2012)

As a former inmate of the detention house 1972-1973 it is always moving to see "your" cell again. May this time never come back. Dr. W.S - - Bayern - (July 2019)

Former prisoners paraphrase their prison term. They use metaphors, such as "been there as a guest" ("zu Gast gewesen sein"), to have "lived" ("gewohnt") in the cell, or to have been "accommodated" ("einquartiert"), to create a verbal distance to their experience. The quotation marks signal the irony underlying their statements.

3 "Heute, nach 56 Jahren, haben wir den "Fuchsbau" wiedergesehen, wo wir einige Wochen "zu Gast" waren. Wir konnten (nach und nach) sogar unsere Zellen identifizieren. Insgesamt sollte man den Fuchsbau etwas mehr Aufmerksamkeit widmen, gehört er doch zu den wichtigsten Erinnerungsplätzen an einen Staat, von dem einige meinen, er sei kein Unrechtsstaat gewesen." D.+W.N. (April 2010).

4 "Großartige Gelegenheit, ein Gefühl für jene Zeit zu bekommen und bei allen, die schon mal hier "gewohnt" haben werden alte Erinnerungen wieder wach. Ich wünsche Ihnen viel Erfolg beim Bemühen, das alles zu erhalten. S.I., Insasse Sept./Okt. 1988” (Sommer 2010).

5 "Die Vergangenheit hat mich eingeholt. Mein "Aufenthalt" in Zelle 7 von April bis Juli 75, als damals $16 j a ̈ h r i g e r$ war furchtbar. Ein Lebensjahr war damals weg, Grund \$213, Flucht. G.H.W. Sonnenallee” (Dezember 2011).

6 "Vor 51 Jahren war ich für 80 Tage in Zelle 25 "einquartiert". Das war damals eine 3-Mann-Zelle mit einer durchgehenden Holzpritsche, so hoch das man kaum sitzen konnte. Legen war verboten. Blieb nur noch abwechselnd auf der Kloschüssel zu sitzen. Da wurde man ab und zu hochgetrieben weil von außen die Spülung betätigt wurde. K.K." (September 2012).

7 "Als ehemaliger Insasse des Hafthauses 1972-1973 immer wieder berührend „seine"Zelle wieder zu sehen. Möge so eine Zeit niemals wieder kommen. Dr. W.S. - Bayern - “ (Juli 2019). 
The communication of their own, and often traumatic, past/experiences in the former detention center of the Stasi is engraved with sometimes ironic and partly sarcastic statements by some of the former Stasi prisoners. It seems that they create a verbal distance to their experience in order to avoid going into the details.

Nice that you can decide the duration of your stay now on your own. Former inmate 1980. (October 2011) ${ }^{8}$

This comment especially points out the irony and sarcasm of a political prisoner of the Stasi. The author refers to the memorial site as a public place that you can visit voluntarily. The former inmate subtly criticizes the arbitrary conviction and duration of arrests in the former Soviet occupation zone and later GDR.

Some former prisoners expressed the mental burden of returning to the place of arrest because they had to suffer there. By analyzing the written comments of these persons, we can only imagine a small part of the emotional dimension. Visiting the memorial site seems to be an important piece of personal reappraisal for the former Stasi prisoners' individual memories, and it also makes them proud that they survived these days, which you can read in the following entries.

It is a great feeling that today my two children are jumping freely through this clink, if someone had told me while I was sitting here in a cell, I did not expect that this was going to move me in such a way. B.F. (August 2010)

I was also here in a time period from Sep 1978 to Dec 1978. The old memories returned here, I was moved to tears by what I had been through. Thank you, for maintaining this place as a memorial site in order not to forget. F.S (January 2012) ${ }^{10}$

Second attempt to enter this place. Did it! Palpitation of the heart, memories. I'm glad I made it. Scum! This Stasi! F., K. (July 2013) ${ }^{11}$

8 "Schön, dass man die Dauer des Aufenthaltes jetzt selbst bestimmen kann. M.S. (Ehemaliger, 1980)" (Oktober 2011).

9 "Es ist ein tolles Gefühl daß heute meine zwei Kinder frei durch diesen Knast springen, wenn mir das damals als ich hier in einer Zelle saßjemand gesagt hätte, ich hab nicht erwartet, daß das mich mal so berührt. B.F." (August 2010).

10 "Ich war auch hier in der Zeit vom Sep 1978 bis Dez 1978. Hier kam mir wieder die alten Erinnerungen hoch, mir kamen die Tränen was ich damals alles durchgemacht habe. Danke, das dieses Gebäude als Erinnerungsstätte erhalten bleibt um nicht zu vergessen. F.S." (Januar 2012).

11 "Zweiter Versuch, dieses hier zu betreten. Geschafft! Herzklopfen, Erinnerungen. Jetzt bin ich froh, dass ich es geschafft habe. Abschaum! Diese Stasi! F., K." (Juli 2013). 
Visiting the former detention center is not a matter of course for former Stasi prisoners. A very short but meaningful comment underlines this.

Here again, this time as a free person. L.U. (January 2015) $)^{12}$

Comments written by or with relatives indicate what the experience of political imprisonment in the GDR means for the family memory. The family memory is a part of what Welzer (2008, p. 164) calls the communicative memory, which is formed by conversations and narratives among a family, which are a natural part of everyday life. On different occasions, families talk about stories and experiences of family members, while the narrator does need to be the story's protagonist.

The entries by former Stasi prisoners' relatives prove that the experience of political imprisonment has become part of the "family heritage". By visiting the memorial site, the families manifest their focus and engagement with the issue.

My brother Bernd was detained here. I can feel with him, so much pain, terrible time after that. Thank you. S.K. (August 2011) 1. $^{13}$

After I was "accommodated" here in 1985, I came here today to show my family how it was! It is good that this is maintained as a witness of a former time. Thank you. Time of imprisonment 18.06.85-10.10.85 KH.B. (Dezember 2011) $)^{14}$

My parents were innocently arrested at this place and it is so cruel when you see it for the first time and imagine what they have been through. One should not forget it! N. H. (June 2012) ${ }^{15}$

Thank you very much for this exhibition that allowed me to learn something about my parents' past. They were remanded in custody here for some days in 1984. I am very proud of them and their political opinions. I was 2 years old and grew up in West Germany. Fortunately, my family found happiness by leaving for the West. R. (July 2012)

12 "Wieder mal hier, diesmal frei. L.U." (Januar 2015).

13 "Mein Bruder Bernd war hier inhaftiert. Ich kann so vieles nachfühlen, so viel Leid, schlimme Zeit danach. Danke. S.K.” (August 2011).

14 "Nachdem ich selbst im Jahre 1985 hier "einquartiert" wurde, habe ich heute nochmals den Ort aufgesucht, um meiner Familie zu zeigen, wie es war! Es ist gut, daß soetwas erhalten bleibt als Zeitzengen. Danke. Haftzeit von 18.06.85-10.10.85. KH.B." (Dezember 2011).

15 "Meine Eltern waren hier unschuldig inhaftiert und das ist so grausam, wenn man dies zum 1.Mal sieht und sich vorstellt, was sie hier durchgemacht haben. Dies darf man nie vergessen! N.H." (Juni 2012).

16 "Vielen Dank für diese tolle Ausstellung, die mir die Möglichkeit gegeben hat etwas über die Vergangenheit und meine Eltern zu lernen. Sie waren 1984 hier für wenige Wochen in U-Haft. Ich bin sehr stolz auf sie und ihre politischen Ansichten. Ich war damals zwei Jahre alt und bin in Westdeutschland aufgewachsen. Es hat zum Glück ein gutes Ende mit meine Familie gefunden, und mit unserer Ausreise in den Westen. R." (Juli 2012). 
Actually I didn't want to, but my wife wanted to see where I was in prison in summer and fall in 1989. My memories of this place didn't fade, although I remembered the building to be bigger. These "little" moments of bondage, I remember: not being able to decide about the headlamp switch; no option to contact anyone; not knowing what happens; one day no more information from the outside, that means no newspaper; being informed about the sentence before; uselessness of the legal counsel, etc. I am happy that everybody can visit the place now. Free, independent and without enforcement. Thank you for that! O.Z. Berlin - imprisoned from July 89 to the end of October (December 2012) ${ }^{17}$

My father was here for $1 / 2-3 / 4$ year. It was very moving! Very nicely arranged. (January 2017) ${ }^{18}$

Now I have seen where my father was remanded in custody 1980. T. (Dezember 2019) $^{19}$

Lest we forget: Thank you for offering an impression and for preserving this memorial site. My father was detained here from 1981 to 1988. L.S $\left(\right.$ January 2020) ${ }^{20}$

You can recognize that some former prisoners visited the memorial site together with their relatives. Other family members visited the authentic place on their own to have a feeling for the narratives and to think about the aspect of political imprisonment as a special part of the family memory. The generational experience of Stasi arrest becomes a trans-generational and metahistorical group experience (Welzer 2008, p. 169) and therefore becomes an inherent part of the family history.

In a lot of former Stasi prisoners' comments or entries written by their relatives, the authors underline the importance of the memorial site Bautzner Straße Dresden for the personal reappraisal of political injustice by victims. See, for instance, the following examples.

17 "Eigentlich wollte ich nicht, doch meine Frau wollte sehen, wo ich im Sommer und Herbst 1989 inhaftiert war. Meine Erinnerung an diesen Ort ist nicht verblasst, obwohl ich das Gebäude größer in Erinnerung hatte. Woran ich bis heute noch denken muss, sind diese "kleinen" Momente der Unfreiheit: nicht Herr über den Lichtschalter zu sein; keine Möglichkeit mit anderen in Kontakt zu treten; nicht zu wissen was passieren wird; irgendwann keine Nachricht mehr von außen zu bekommen, d.h. keine Zeitung mehr; bereits vorher das Strafmaßzu erfahren; die Nutzlosigkeit der Rechtsvertretung etc. Ich bin froh, dass jeder den Ort begehen kann. Frei, unabhängig und ohne Zwang. Danke dafür! O.Z., Berlin - inhaftiert vom Juli 89 bis Ende Oktober” (Dezember 2012).

18 “Mein Vater war hier 1/2-3/4 Jahr. Es war sehr berührend! Sehr schöne Gestaltung." (Januar 2017).

19 "Nun habe ich endlich einmal gesehen, wo mein Vater 1980 in Untersuchungshaft gesessen hat. T." (Dezember 2019).

20 "Gegen das Vergessen: Danke für die Einsicht und den Erhalt dieser Gedenkstätte. Mein Vater war von 1981-1988 hier inhaftiert. L.S.” (Januar 2020). 
Upsetting to have this setting in the mind's eye again, but it should not be forgotten! Prisoner from January-April 1979: G.L. (January 2019) ${ }^{21}$

Thank you on behalf of the prisoners' relatives that you preserve this site for remembering! P.L. (Daughter of Ms. S.F.) (Sommer 2012) ${ }^{22}$

The memorial site Bautzner Straße Dresden offers an opportunity for the Stasi prisoners' individual memories as well as for the family memories to deal with the authentic place and the experiences that took place there. The Stasi arrest narratives can be transgenerational, experienced by walking through the former Stasi complex. The plurality and intensity of victims' comments in the visitor books emphasize the memorial site as a place of personal reencounter and the private and public memory of their burden (Hattig et al. 2006, p. 407).

\section{Conclusion}

A lot of visitor book entries underline the importance of the reappraisal of instances of political injustice. Today, there is no need to ask whether dictatorships deserve places to remember in what Sabrow (2013, p. 322) calls our memory society. Those places that remember the communist dictatorship are an inherent part of the German memorial site landscape. And, nearly every memorial site has a visitor book that offers to comment on the exhibition or the institution, anonymously or by identifying oneself.

I would like to outline my three main findings of the comments' analysis. My first finding is that former prisoners paraphrase their prison term to create a verbal distance to their Stasi prison experience.

Furthermore, I found out that returning to the place of ordeal is - in the comments of former Stasi prisoners - described as an inner fight. On the site, the relief of being a free person outweighs the struggle before visiting. It could also be seen as a process of individual recovery. Former political prisoners in the GDR were often traumatized by their experience. Dealing with this experience is a very individual and dynamic process that takes time - and courage. This conclusion emphasizes the memorial site's duty to be a place of personal reencounter.

Last but not the least, I examined the effect of the visit to the memorial site for relatives. The comments by relatives and descendants underline the significance for the family memory: Through visiting the memorial site and

21 "Erschütternd, dieses Szenario wieder vor Augen zu haben, doch es sollte nicht vergessen werden! Häftling von Januar - April 1979: G.L." (Januar 2012).

22 "Ich danke Ihnen im Namen der Angehörigen der hier Inhaftierten, daß Sie diese Stätte im Gedenken erhalten! P.L. (Tochter von Frau S.F.)” (Sommer 2012). 
being confronted at the historical place, relatives and descendants take part in a generational experience that affects them intensively.

As I mentioned at the beginning, I identified entry rates from $1.0 \%$ to $2.7 \%$ of the visitors per annum (2010-2020). A majority of visitors decide not to write something down and do not take the offer of replying to something of what they have seen. Writing a comment does not seem to be delightful for a lot of people. Interestingly though, I found a lot of entries of people who identified themselves as former Stasi prisoners. For visitors who write a comment, this could have different functions. There is space to write down the emotional reactions to the visit and, therefore, visitor books can be seen as a kind of outlet to deal with the experience. Entries of this kind are especially moving and are evidence of the importance of visitor books.

Their limited empirical representativeness is outweighed by the specific emotions and intensity conveyed in the comments. All in all, I think it is worth taking a closer look because it offers unique access to visitors' reactions. The systematic analysis of visitor books can offer new approaches for visitor research. I especially see potentials in gaining access to the range of reactions experienced during memorial site visits by combining different methodical approaches, in addition to adjusting or modulating the educational proposals or intentions of memorial sites in general.

\section{References}

Assmann, Jan. 2007. Das kulturelle Gedächtnis: Schrift, Erinnerung und politische Identität in frühen Hochkulturen, 6th edn. München: Beck.

Boeger, Peter, and Elise Catrain (eds.). 2017. Stasi in Sachsen. die DDR-Geheimpolizei in den Bezirken Dresden, Karl-Marx-Stadt und Leipzig. Berlin: Der Bundesbeauftragte für die Unterlagen des Staatssicherheitsdienstes der ehemaligen Deutschen Demokratischen Republik.

Christmeier, Martina. 2009. Besucher am authentischen Ort: Eine empirische Studie im Dokumentationszentrum Reichsparteitagsgelände. Idstein: Schulz-Kirchner.

Gallinat, Anselma, and Sabine Kittel. 2009. Zum Umgang mit der DDR-Vergangenheit heute: Ostdeutsche Erfahrungen, Erneuerungen und Identität. In Friedensstaat, Leseland, Sportnation?: DDR-Legenden auf dem Prüfstand, ed. Thomas Großbölting, 304-328. Berlin: Christoph Links Verlag.

Glogner-Pilz, Patrick. 2019. Kulturpublikumsforschung: Grundlagen und Methoden, 2nd edn. Wiesbaden: Springer Fachmedien Wiesbaden.

Hattig, Susanne, Lothar Klein, and Klaus-Dieter Müller. 2006. Gedenken-Forschen-Lernen. Die DDR-Diktatur in sächsischen Gedenkstätten. Bildung und Erziehung BuE 59 (4): 407-421. 
Kaminsky, Anna (ed.). 2016. Orte des Erinnerns: Gedenkzeichen, Gedenkstätten und Museen zur Diktatur in SBZ und DDR. Bonn: Bundeszentrale für politische Bildung.

Macdonald, Sharon. 2005. Accessing Audiences: Visiting Visitor Books. museum and society 3 (3): 119-136.

Müller, Ulrich. 2003. „Die Lektüre dieses Buches ist so interessant...“ Zur Analyse der Besucherbücher der Mahn- und Gedenkstätte Düsseldorf 1988-1999. Augenblick. Berichte, Informationen und Dokumente der Mahn- und Gedenkstätte Düsseldorf (26/27): 32-39.

Sabrow, Martin. 2013. Die postheroische Gedächtnisgesellschaft: Bauformen des historischen Erzählens in der Gegenwart. In Geschichtspolitik in Europa seit 1989: Deutschland, Frankreich und Polen im internationalen Vergleich, ed. Etienne Francois, Kornelia Konczal, Robert Traba and Stefan Troebst, 311-322. Göttingen: Wallstein Verlag.

Sieber, Uljana, and Katrin Thiel. 2017. Dresden, Bautzner Straße: Von der MfS-Verwaltung zur Gedenkstätte. Berlin: Links, Ch.

Thurmair, Maria. 2009. Die Glasarche-Bücher als Textsorte im Spektrum anderer Besucherbücher: Gipfelbücher, Anliegenbücher, Museumsbücher. In Ein Kunstobjekt als Schreibanlass: Die deutsch-tschechische Reise der „Glasarche“ im Spiegel ihrer Besucherbücher, ed. Heiko Hausendorf, 37-62. Regensburg: Ed. Vulpes.

Welzer, Harald. 2008. Das kommunikative Gedächtnis: Eine Theorie der Erinnerung, 2nd edn. München: Beck. 